\title{
Design Of Distribution Board Unit For A Business Focus
}

\author{
M. O. Oyeleye
}

\begin{abstract}
This research focus on adequate sizing of miniature circuit breakers (MCBs) and Molded Case Circuit Breaker (MCCB) of distribution board unit for a business center/focus. The aim of this research is to overcome the tripping and burning of connected loads in the study area. The load survey of the business center was carried out and the current rating of the associated equipment used were computed, using the data obtained from the name plate of the equipment. The rated values of the existing MCBs and MCCB were compared with the recommended values obtained from international codes in order to determine the inadequacy of the existing ones in term of protection for the connected load. The result obtained shows that $11 \%$ of the load are adequately protected against over current, $6 \%$ of the existing load is under-rated while $83 \%$ of the load were not over current protected in the existing DB. Re-design the DB protective devices was carried out in accordance with the international codes to avoid tripping and frequent burning of loads. The number of MCBs resigned is 22.5 single phase MCBs. 23 single phase DB are not readily available, three phase, 8-Way DB is recommended with $25 \%$ future expansion. The voltage drop for the cable between the MCCB and the supply source is lesser $(0.4 \%)$ than $3 \%$ recommended by NEC. $100 \%$ of the load are protected in the new design hence protection for all the connected loads against overcurrent damage thus removing tripping and burning of many connected loads in the studied area Equation to size DB is proposed in this work. Overcurrent protective device (CB) must conform to international standard of $\mathbf{1 . 2 5}$ multiplying factor in order to adequately protect the intending load. This is necessary to reduce cost of maintenance and or otherwise procurement of new one. It is also necessary to avoid disruption of work or service.
\end{abstract}

Index Terms-Distribution Board, Circuit breaker, Fuse, miniature circuit breakers and Molded Case Circuit Breaker.

\section{INTRODUCTION}

Electricity is dangerous and required proper protection to prevent unwanted voltage from passing through personnel, critical equipment and other nearby metallic objects [1].

The security and reliability of the electrical energy infrastructure is of vital importance today more than ever, given the degree to which electric-powered technology has become embedded in all human activities. Protecting the electrical power supply system against interruptions due to various faults is researchable [2]. One of the components involved in power-system protection is the circuit breaker which is responsible for breaking the system when a fault or anomaly occurs in order to protect the electrical equipment $[3,4]$. Circuit breakers are crucial components for power systems operation for detection and removal of faults in the switchgear. [5]
Moreover, electrical protection for residential, office and commercial buildings is based on a well- design circuit breaker that will trip or fuses being blown when an overload happens $[6,10]$.The current state-of-the-art in this field highlights that the traditional circuit breakers are still widely used today for power-system protection, these devices being usually designed to protect against a single power supply grid fault [7]. MCCBs are required to trip above rated current [8]

This research work critical reviewed a business center with the intention to overcome the aforementioned side effects of electricity supply. This is achieved in this work by critical review of a business center $\mathrm{DB}$, noting the existing MCBs and MCCB rated values, compare it with the international standards, and redesigned where necessary. This is to solve the problem of damaging $\mathrm{AC}$ and the associated connected loads by proper operation of Distribution Board (DB) in order to ensure that fault will be isolated at the lowest level. Apart from life of the equipment users, the replacement of damaged equipment is monetary. This is an economic loss to the end users.

This work is also done to enlighten or educate the electrical engineer to design a DB to standard. Many electrical engineering graduates leave the design of a DB to the hand of technicians and technologies designer which is very wrong. The DB designs and inspections of designed $\mathrm{BD}$ according to the design is very necessary. This work is of the opinion that $\mathrm{MCB}$ and $\mathrm{MCCB}$ designers will tremendously gain to size these protective devices.

\section{Distribution Board}

In most buildings, where a number of circuits are to be wired, the distribution fuse board becomes a necessity. Distribution boards are simply an assemblage of parts including one or more fuses or circuit breakers suitably arranged for the distribution of electrical power to final sub circuits. [9]. The circuit breakers are on suitable carriers with neutral and earth bars adequately provided inside a metal casing. The metal casing shall be of adequate size and capacity. They are usually iron clad and designed to provide a large space for wiring and splitting the circuits. It consist circuit breakers or fuse inside which can easily remove. The DB understudy contains CBs due to $\mathrm{CB}$ advantage over fuse which will be mentioned later. The purpose of this study is to verify the proper operation of Distribution Board (DB) and re-design appropriate DB for the business center under consideration to ensure that fault will be isolated at the lowest level. 


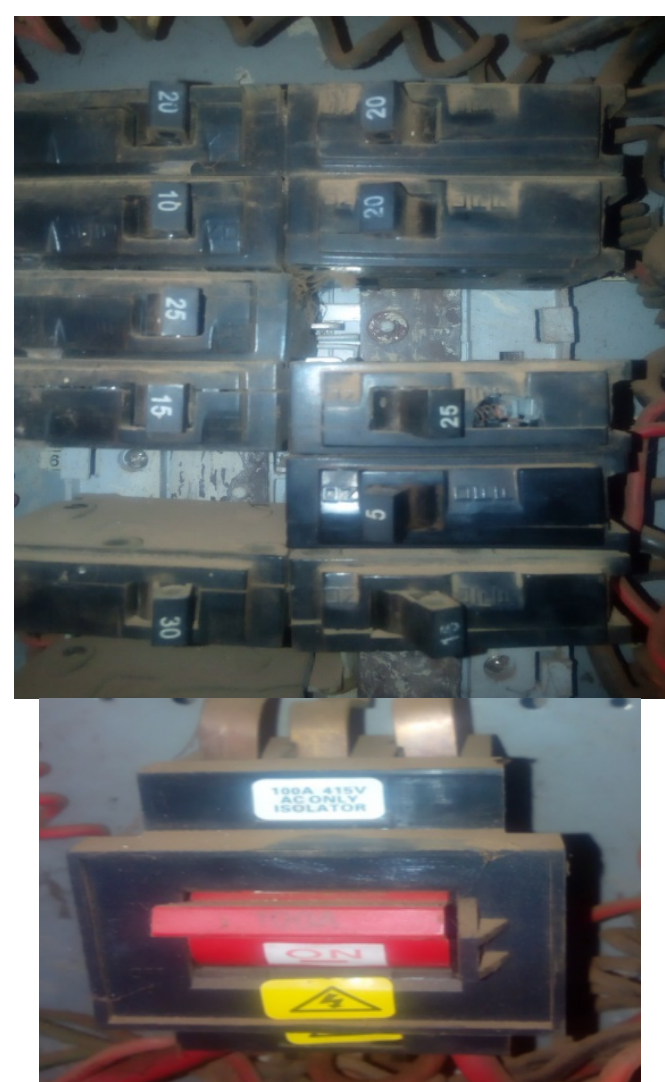

Fig. 1. Existing MCB and MCCB Rating. The existing DB MCBs and MCCB showing their ratings.

\section{Elements of Distribution Board}

The distribution board consists of the following:

\section{i. Fuses}

Fuse is the safety device and the weakest part of the electrical system. It consist of a small link to the soft metal which melts when excessive current passes through it [10]. The fuse wires are usually bare wires and are made of lead and tin. Lead alloy for small current and tinned copper wire issued for large current. However, fuse need no maintenance and its the cheapest form of protection available. It main disadvantage is wrong rewiring when it cuts and time delay when compare to circuit breaker which leads to damage of the connected equipment to be protected. Due to this, fuse is not used in the design $[11,12]$.

\section{ii. Circuit Breakers}

These are automatic electrical switches designed to protect an electrical appliance from damage when drawing current above its rated value $[13,15]$. It basic function is to detect faults. Unlike fuses, they can be reset (manually or automated) after a break. This existing ability is an advantage over Fuse [13, 12].

\section{Miniature Circuit Breaker (MCB).}

$\mathrm{MCB}$ is an electromechanical device which guards an electrical circuit from an over current that may arise from short circuit, overload or defective design. An MCB can be simply rearranged and thus gives a better operational protection and greater handiness with lesser cost. The operating principle of MCB is simple. An MCB function by interrupting the stability of electrical flow through the circuit once an error is detected. In simple conditions this circuit breaker is a switch which routinely turns off when the current flows through it and passes the maximum acceptable limit. Generally, these are designed to guard against over current and overheating. MCB is substituting the rewirable switch-fuse units for low power domestic and industrial applications in a very quick manner. In wiring system, the MCB is a blend of all three functions such as protection of short circuit, overload and switching. Protection of overload by using a bimetallic strip and short circuit protection by used solenoid [13]. It is a better option to a fuse especially when overload devices is so frequent as to make the use of the fuses impractical. It is used in distribution board final sub circuit.

The characteristics of an MCB mainly include the following: rated current is not more than 100 amperes, normally, trip characteristics are not adjustable and thermal/thermal magnetic operation [12].

\section{Earth Leakage Circuit Breaker (ELCB):}

ELCB is a device used in electrical system with high earth impedance to avoid shock. It notices small stray voltages on the metal fields of electrical gear, and interrupt the circuit if an unsafe voltage is detected. The main principle of Earth leakage protectors is to stop injury to humans and nature due to electric shock. This circuit breaker is a specialized kind of latching relay that has structures incoming mains power connected through its switching contacts so that this circuit breaker disconnects the power supply in an unsafe condition.

The ELCB notices fault currents from live to the ground wire inside the installation it guards. If enough voltage emerges across the sense coil in the circuit breaker, it will turn off the supply, and stay off until reset by hand. A voltage-sensing earth leakage circuit breaker doesn't detect fault currents from exist to any other ground body [13].

Characteristics of ELCB include the following, this circuit breaker connects the phase, earth wire and neutral and the working of this circuit breaker depends on current leakage [12].

\section{Residual Current Circuit Breaker (RCCB):}

A RCCB is an essential current sensing equipment used to guard a low voltage circuit from the fault. It comprises of a switch device used to turn off the circuit when a fault occurs in the circuit. RCCB is aimed at guarding a person from the electrical shocks. Fires and electrocution are caused due to the wrong wiring or any earth faults. This type of circuit breaker is used in situations where there is a sudden shock or fault happening in the circuit.

For instance, a person suddenly enters in contact with an open live wire in an electrical circuit. In that situation, in the absence of this circuit breaker, a ground fault may occur and an individual is at the hazardous situation of receiving a shock. But, if the similar circuit is defended with the circuit breaker, it will tour the circuit in a second therefore, avoiding a person from the electric shock. However, this is not used in the design since the existing business centre DB does not have the facility. The characteristics of an RCCB mainly include: both wires phase and neutral are connected through RCCB, whenever there is any ground fault occurs, then it trips the circuit, The amount of current supplies through the line should go back through neutral and these are a very effective type of shock protection $[12,13]$. 


\section{Molded Case Circuit Breaker (MCCB)}

The MCCB is used to control electric energy in distribution network and is having short circuit and overload protection. This circuit Breaker is an electromechanical device which guards a circuit from short circuit and over current. They offer short circuit and over current protection for circuits ranges from 63 Amps-3000 Amps. The primary functions of MCCB is to give a means to manually open a circuit, automatically open a circuit under short circuit or overload conditions. In an electrical circuit, the over current may result faulty design. The MCCB is an option to a fuse since it doesn't need an alternate once an overload is noticed. Unlike a fuse, this circuit breaker can be simply reset after a mistake and offers enhanced operator safety and ease without acquiring operating cost. Generally, these circuits have thermal current for over current and the magnetic element for short circuit release to work faster [13, 11]. The power rating of MCCB is higher than that of MCBs.

The characteristics of an MCCB mainly include: the range of rated current us up to 1000 amperes, trip current may be adjusted and thermal/thermal magnetic operation $[13,11]$. It is believe that in the absence of RCCB and ELCB the circuit is till protected against overload. With effective earthing system, earth fault will be discharge safely to the ground. The non-usage of RCCB and ELCB will reduce the cost of installation.

\section{Distribution of Metallic Case}

The metallic enclosure shall be dust and weather proof and have a mounting arrangement on a wall. This closure will have an earthing terminal and it will be interlocked with the actuating lever to prevent access to the interior whilst the lever is in the on position. Fixed contacts and other metal parts shall be nickel plated or tinned where it is desirable [10].

\section{MCCB Cable Sizing}

In selecting the proper size conductors for supplying power in circuit from the source to the load. It is most important that the designer apply the appropriate standards. In the case of power service the electrician usually selects the cable size to corresponding capacity of the circuit breaker at the distribution board. However, voltage drop should be considered because it affect the cable sizing especially the MCCB cable [15]. The overcurrent protection conductors and equipment shall be sized in such a way to open the circuit if the currents research a value that causes excessive or dangerous temperature in conductors [16]. The conductors allowable ampacity according NEC are based on four determine factors which are ambient temperature, Heat generated internally, Dissipation into ambient medium and adjacent load carry conductors [12]. However, conductor shall be sized to carry the load current without deteriorating the insulation.

\section{i. Derating Factor}

This is a factor that consider reduction in actual rating capacity of the cable. The actual rating of the cable is reduce by a certain factor if it is more than one running in parallel.
It is a factor that consider safe heating of the cable when more than one cable in parallel.

\section{ii. Voltage Drop}

Cables have resistance which oppose the flow of currents through them, which leads to voltage drop. The voltage at the load is lower than the supply voltage by the amount of the voltage drop across the cable which depends on the length of the cables. These losses normally result in heating of the cables and at the same time cause temperature rise to such degree that can damage or completely destroy the cable insulation. However the rate at which heat in the cable take place depend on conductor material, surface area and thickness of the insulation [9]. Most manufacturers recommends that voltage drop should be $1 \%$ however NEC limits the voltage drop to $3 \%$ in a branch circuit to avoid power quality problem in a branch circuit $[15,16]$.

\section{Multiply Factor}

The multiplying factor considered in this research in sizing of cable is based on the NEC code as presented in Table 1.

\section{Design considerations}

Design consideration in this research are namely:

1. location of the panel

2. load rated value

3. phase requirement

4. future expansion of the DB

\section{Applicable Design Standards}

The applicable design codes from international organization and reliable literature are summed up in Table 1.

TABLE I: DESIGN CODE FOR SIZING A DISTRIBUTION BOARD $[12,15,16]$

\begin{tabular}{|l|l|c|}
\hline S/N & ELEMENTS & $\begin{array}{l}\text { CODE(MULTIPLYING } \\
\text { FACTOR }\end{array}$ \\
\hline 1 & $\begin{array}{l}\text { Miniature circuit } \\
\text { breaker }\end{array}$ & 1.25 \\
\hline 2 & $\begin{array}{l}\text { Mould case circuit } \\
\text { breaker }\end{array}$ & 1.25 \\
\hline 2 & Cable/conductor & 1.25 \\
\hline 3 & $\begin{array}{l}\text { Load future } \\
\text { expansion }\end{array}$ & 1.25 \\
\hline
\end{tabular}

\section{Methodology}

\section{Load Survey}

Load survey of the installed load was carried out. The circuit numbers were established by counting the number of equipment /item installed and ascertain the circuit by tracing the wire. Each circuit was traced to its miniature circuit breaker (MCB).

\section{i. Design of $M C B$ and MCCB Rating}

Each load on a circuit breaker was determined using the name plate on the concerned load. The load was given in wattage or voltage-ampere and this is converted into current using equation (1).

$$
P=I_{P h} V_{p h} \operatorname{CoS} \varnothing
$$

Where $\mathrm{I}_{\mathrm{ph}}$ is the phase current, $\mathrm{V}_{\mathrm{ph}}$ is the single phase voltage $\operatorname{Cos} \emptyset$ is the power factor.

Applicable codes were applied to the calculated current (rated) as in Table 1 to size CB. Where the calculated CB is 
not available, the closed rating is recommended as in Table 3.

TABLE II: BUSINESS CENTRE LOAD SURVEY

\begin{tabular}{|l|l|l|}
\hline S/N & ELECTRICAL LOADS (1-Ph, 0.8 pf) & $\begin{array}{l}\text { NO } \\
\text { OF } \\
\text { CCT }\end{array}$ \\
\hline 1 & $\begin{array}{l}\text { 19 nos of 2 x 36 W fluorescence Tubes for internal } \\
\text { lighting }\end{array}$ & 1 \\
\hline 2 & 6 nos of 750VA office Printer & 6 \\
\hline 3 & $\begin{array}{l}12 \text { nos of 1 x 18W lobby light } \\
\text { dedicated circuit) }\end{array}$ & 1 \\
\hline 4 & $\begin{array}{l}\text { 2 nos of 400W incandescent lamps for external } \\
\text { lighting }\end{array}$ & 3 \\
\hline 6 nos of 2Amp freezers(each connected to a & 2 \\
\hline 7 & $\begin{array}{l}3 \text { nos of 2000W electric kettle(each connected to a } \\
\text { dedicated circuit) }\end{array}$ & 3 \\
\hline 8 & $1.7 \mathrm{~A}$ Dell lap top & 1 \\
\hline & \multicolumn{1}{|c|}{ Total } & 18 \\
\hline
\end{tabular}

\section{ii. Adequacy of $M C B$ and $M C C B$ Rating}

The existing MCBs and MCCB were compared with the recommended values in order to determine the adequacy of the existing ones in term of protection of the connected loads.

\section{iii. $\quad$ Sizing of Distribution Board}

Sizing of Distribution Board is given by equation (2) for single phase

$$
S_{T N}=C_{T N} x \quad M_{f}
$$

From equation (2), equation (3) is obtained for three phases

$$
S_{T N}=\frac{C_{T N} \times M_{f}}{P_{n o}}
$$

Where $\mathrm{C}_{\mathrm{TN}}$ is number of circuit, $\mathrm{M}_{\mathrm{f}}$ is future expansion multiplying factor and $\mathrm{P}_{\mathrm{no}}$ is number of circuit.

\section{$\underline{\text { Voltage Drop Calculation }}$}

The voltage drop is determine using Equation (4):

$$
V_{\text {drop }}=D x I_{\text {rated }} x \frac{V}{\text { Amp } / \text { meter }}
$$

Where $\mathrm{D}$ is the distance and $V$ is voltage drop of cable according to the manufacturer.

\section{RESUlts AND ANALYSIS}

The result of the Business centre load survey is presented in Table 1.

From Table 2, individual Printer, air-condition, freezer and electric kettle conform to dedicated circuit rule. It follows that the loads are adequately circuit.

The result of $\mathrm{MCB}, \mathrm{MCCB}$ and $\mathrm{CB}$ is presented in Table 2.

From Table 3 only item 10 and 18 were adequately protected. Other elements were not protected. The CBs were overrated. Figure 1 attestates to inadequate protection of the installed element at a glance. It follows that, the over rating of the MCBs will not be able to trip the connected load in case of some fault. The over-rating is also shown in Figure 1.

Item number 16, is under rated. It means it will be tripping on the connected load.

From equation 4, the voltage drop is less than $1 \mathrm{~V}$. It means that voltage drop tolerable sine it is less than acceptable $3 \%$ by NEC.

From equation (2), the number of MCBs designed is 22.5 single MCBs. 22.5 or 23 single phase DB are not readily avaible, three phase DB is used. From equation (3), it is designed to 7.5 - Way. Since there is no 7.5 - way, 8-Way is recommended. It means that there is $6 \mathrm{MCBs}$ as spare which is conform to $25 \%$ future expansion.

\section{CONCLUSIONS AND RECOMMENDATIONS}

\section{A. Conclusions}

The following conclusions are deduced from this research:

i. The existing loads are adequately circuit.

ii. MCCB cable complied with voltage drop criterion.

iii. $11 \%$ of the load are adequately protected against over current in the existing DB.

iv. $83 \%$ of the load failed over current protection existing $\mathrm{DB}$, this contributed to frequent burning of the connected loads.

v. $6 \%$ of the existing load is under-rated existing DB, this contributed to its tripping.

vi. the existing DB has no provision for spare.

vii. $100 \%$ of the load are protected in the new design hence protection for all the connected loads against overcurrent damage.

viii. the new design $\mathrm{DB}$ has $25 \%$ future expansion.

\section{B. Recommendations}

It is recommended that overcurrent protective device (CB) must conform to international standard of $25 \%$ multiplying factor in order to adequately protect the intending load. This is necessary to reduce cost of maintenance and or otherwise procurement of new one. It is also necessary to avoid disruption of work or service.



Fig. 2. MCB, MCCB and Cable Sizing. 
TABLE III: MCB, MCCB AND CABLE SIZING

\begin{tabular}{|c|c|c|c|c|c|c|c|c|c|c|c|c|c|}
\hline $\mathbf{S} / \mathbf{N}$ & $\begin{array}{l}\text { Electrical loads } \\
(1-\mathrm{Ph}, 240 \mathrm{~V})\end{array}$ & CCT & LOAD & $\begin{array}{l}\text { Total } \\
\text { (W) }\end{array}$ & $\mathbf{I}(\mathbf{A})$ & $\mathbf{M}_{\mathbf{f}}$ & $I^{*} \mathbf{M}_{\mathbf{f}}$ & $\begin{array}{l}\text { CB } \\
\operatorname{Rec} \\
(\mathbf{A})\end{array}$ & $\begin{array}{l}\text { CB) } \\
\text { Existing } \\
\text { (A) }\end{array}$ & $\begin{array}{l}\text { CCT } \\
\text { Situation }\end{array}$ & $\begin{array}{l}\text { Cable, } A \\
\left(I^{*} M_{f}\right. \\
* 1.25)\end{array}$ & $\begin{array}{l}\text { Cable } \\
\text { Sizing } \\
1.5 \mathrm{~mm}^{2}\end{array}$ & Effect \\
\hline 1 & $\begin{array}{l}19 \text { nos of } 2 \times 36 \mathrm{~W} \\
\text { fluorescence Tubes } \\
\text { for internal } \\
\text { lighting }\end{array}$ & 1 & $72 \mathrm{~W}$ & 1296 & 6.75 & 1.0 & 6.8 & 10 & 20 & Over-rated & 8.4 & 1 & Damage \\
\hline 2 & $\begin{array}{l}1 \text { no of } 750 \mathrm{VA} \\
\text { office Printer }\end{array}$ & 1 & $750 \mathrm{VA}$ & 750 & 3.91 & 1.25 & 4.9 & 5 & 20 & Over-rated & 6.1 & 1.5 & Damage \\
\hline 3 & $\begin{array}{l}1 \text { no of } 750 \mathrm{VA} \\
\text { office Printer }\end{array}$ & 1 & $750 \mathrm{VA}$ & 750 & 3.91 & 1.25 & 4.9 & 5 & 10 & Over-rated & 6.1 & 1.5 & Damage \\
\hline 4 & $\begin{array}{l}1 \text { no of } 750 \mathrm{VA} \\
\text { office Printer }\end{array}$ & 1 & $750 \mathrm{VA}$ & 750 & 3.91 & 1.25 & 4.9 & 5 & 20 & Over-rated & 6.1 & 1.5 & Damage \\
\hline 5 & $\begin{array}{l}1 \text { no of } 750 \mathrm{VA} \\
\text { office Printer }\end{array}$ & 1 & $750 \mathrm{VA}$ & 750 & 3.91 & 1.25 & 4.9 & 5 & 10 & Over-rated & 6.1 & 1.5 & Damage \\
\hline 6 & $\begin{array}{l}1 \text { no of } 750 \mathrm{VA} \\
\text { office Printer }\end{array}$ & 1 & $750 \mathrm{VA}$ & 750 & 3.91 & 1.25 & 4.9 & 5 & 10 & Over-rated & 6.1 & 1.5 & Damage \\
\hline 7 & $\begin{array}{l}1 \text { no of } 750 \mathrm{VA} \\
\text { office Printer }\end{array}$ & 1 & $750 \mathrm{VA}$ & 750 & 3.91 & 1.25 & 4.9 & 5 & 20 & Over-rated & 6.1 & 1.5 & Damage \\
\hline 8 & $\begin{array}{l}6 \text { no of } 18 W \text { lobby } \\
\text { light }\end{array}$ & 1 & $18 \mathrm{~W}$ & 108 & 0.56 & 1.0 & 0.6 & 5 & 10 & Over-rated & 0.7 & 1.5 & Damage \\
\hline 9 & $\begin{array}{l}1 \text { nos of } 1 \mathrm{HP} \text { Air } \\
\text { conditioning }\end{array}$ & 1 & $746 \mathrm{~W}$ & 1296 & 6.75 & 1.25 & 8.4 & 10 & 25 & Over-rated & 10.5 & 2.5 & Damage \\
\hline 10 & $\begin{array}{l}1 \text { nos of } 1 \mathrm{HP} \text { Air } \\
\text { conditioning }\end{array}$ & 1 & $746 \mathrm{~W}$ & 1296 & 6.75 & 1.25 & 8.4 & 10 & 10 & Protected & 10.5 & & Save \\
\hline 11 & $\begin{array}{l}1 \text { nos of 1HP Air } \\
\text { conditioning }\end{array}$ & 1 & $746 \mathrm{~W}$ & 1296 & 6.75 & 1.25 & 8.4 & 10 & 25 & Over-rated & 10.5 & 2.5 & Damage \\
\hline 12 & $\begin{array}{l}2 \text { nos of } 400 \mathrm{~W} \\
\text { incandescent } \\
\text { lamps for external } \\
\text { lighting }\end{array}$ & 1 & $400 \mathrm{~W}$ & 800 & 4.17 & 1.0 & 4.2 & 5 & 10 & Over-rated & 5.2 & 2.5 & Damage \\
\hline 13 & $\begin{array}{l}1 \text { nos of } 2 \mathrm{Amp} \\
\text { freezers }\end{array}$ & 1 & $2 \mathrm{~A}$ & 384 & 2.00 & 1.25 & 2.5 & 5 & 10 & Over-rated & 3.1 & 1.5 & Damage \\
\hline [15] & $\begin{array}{l}1 \text { nos of } 2 \text { Amp } \\
\text { freezers }\end{array}$ & 1 & $2 \mathrm{~A}$ & 384 & 2.00 & 1.25 & 2.5 & 5 & 10 & Over-rated & 3.1 & 1.5 & Damage \\
\hline 15 & $\begin{array}{l}1 \text { nos of } 2000 \mathrm{~W} \\
\text { electric kettle }\end{array}$ & 1 & $2000 \mathrm{~W}$ & 2000 & 10.42 & 1.25 & 13.0 & 15 & 10 & Under-rated & 16.3 & 2.5 & Tripping \\
\hline 16 & $\begin{array}{l}1 \text { nos of } 2000 \mathrm{~W} \\
\text { electric kettle }\end{array}$ & 1 & $2000 \mathrm{~W}$ & 2000 & 10.42 & 1.25 & 13.0 & 15 & 20 & Over-rated & 16.3 & 2.5 & Damage \\
\hline 17 & $\begin{array}{l}1 \text { nos of } 2000 \mathrm{~W} \\
\text { electric kettle }\end{array}$ & 1 & $2000 \mathrm{~W}$ & 2000 & 10.42 & 1.25 & 13.0 & 15 & 10 & Over-rated & 16.3 & 2.5 & Damage \\
\hline 18 & 1.7A Dell lap top & 1 & $1.7 \mathrm{~A}$ & 1296 & 6.75 & 1.25 & 8.4 & 10 & 10 & Protected & 10.5 & 1.5 & Save \\
\hline & Total & 18 & & 18656 & 97.2 & & 118.6 & 125 & 100 & Under-rated & {$[15] 8.2$} & 157 & Damage \\
\hline
\end{tabular}

\section{REFERENCES}

[1] Oyeleye, M.O. Evaluation and planning of lightining protection efficacy on Nigerian high voltage installations.Ikorodu $11 \mathrm{kV}-132 \mathrm{kV}$ system as case study. Phd thesis Federal university of Technology Akure, Nigeria 2017, pp.122-125 pg 192

[2] Yuan W, Zhao L, Zeng B. Optimal power grid protection through a defender-attacker-defender model. Reliability Engineering \& System Safety. 2014;121:83-89.

[3] Liu J, Huang GM, Ma Z, Geng Y. A novel smart high-voltage circuit breaker for smart grid applications. IEEE Transactions on Smart Grid. 2011;2(2):254-264.

[4] Jay Kumar et al. Password Based Circuit Breaker. International Journal of Recent Research Aspects. Issue 1, March 2016, pp 80-88.

[5] Omokhafe J. T, and Ambafi G. J. 2011, Innovations in Science and Engineering, Vol.1, PP.104-114, www.woaj.org/ISE

[6] Sankaranarayanan. Android based smart home monitoring using wireless sensors. IEEE conference on clean energy Technolohgy (CEAT), 2013 DOI: 10.1109/CEAT. 2013.6775683.

[7] Launches E. Arc Fault Detection Device to Reduce Electrical Safety Risk, Eaton Company Press Release; 2016.

[8] Jim P. and Sandi Y. (1996); Sizing a Circuit Breaker https://www.ecmweb.com/basics/sizing-circuit-breaker, Accessed 12 August, 2019.

[9] Ewesor, P.O. Practical Electrical systems installation, work and practice. Frankue partners technical and Engineering Company published by Ambik press ltd, Benin city pp.318.,
[10] J.B . Gupta. A course in Electrical Installation Estimating and Costing 8th edition. Publisher S.K Kataria and Sons, 6, Guru Nanak Market Nai sarak Delhi 110006. 2005 pg. 497.

[11] Marrano J. S. and Dilouie C.E.M. Electrical system design and specification handbook for industrial facilities. Publisher The Fairmont press, 700 indian Trail Lilburn, GA 30047, 1998, pp 437

[12] J. Stallcup's. Electrical design book published by Jones and Bartlett London, 2005, pp 9- 30.

[13] Jigupamar. Difference between MCB, MCCB, ELCB and RCCB, Electrical Engineering Portal October, 2011, https://electricalengineering-portal.com.

[14] Amrapali. D. and Warsha, k. Electronic Circuit Breaker. International Research Journal of Engineering and Technology (IRJET) e-ISSN: 2395 -0056 Volume: 04 Issue: 07 | July -2017 www.irjet.net

[15] B. Kennedy. Power quality primer publisher McGraw-Hill Inc, London, 2000, pg 361.

[16] National electrical code, NEC. International series, 2005, pp. 711.

[17] M. O. Oyeleye (2019). Design of $11 / 0.415 \mathrm{kV}$ substation using applicable international codes. journal of multidisciplinary engineering science studies. 